\title{
Commentary: A superb and meticulous technique, but needs cautious, lifelong follow-up
}

\author{
Kenji Minatoya, MD, PhD
}

\author{
From the Department of Cardiovascular Surgery, Graduate School of Medicine, Kyoto University, Kyoto, Japan. \\ Disclosures: Author has nothing to disclose with regard to commercial support. \\ Received for publication Sept 10, 2019; revisions received Sept 10, 2019; accepted for publication Sept 11, 2019; \\ available ahead of print Oct 22, 2019. \\ Address for reprints: Kenji Minatoya, MD, PhD, 54 Kawaharacho, Shogoin, Sakyo-ku, Kyoto 6068507, Japan \\ (E-mail: minatoya@kuhp.kyoto-u.ac.jp). \\ J Thorac Cardiovasc Surg 2020;159:e101-2 \\ 0022-5223/\$36.00 \\ Copyright (C) 2019 by The American Association for Thoracic Surgery \\ https://doi.org/10.1016/j.jtcvs.2019.09.056
}

Loeys-Dietz syndrome (LDS) causes spontaneous aneurysm and dissection of central and peripheral arterial beds. ${ }^{1,2}$ Therefore, aneurysmal change could follow at the anastomosis with the native aortic tissue after graft replacement. In this issue of the Journal, Tenorio and colleagues ${ }^{3}$ reported endovascular repair of large intercostal artery patch aneurysm using a branch stent-graft in a patient with LDS. Their sophisticated technique for the difficult procedure was described with excellent illustrations. I applaud the authors for the successful results.

Two issues emerge out of this case report. First is the patch aneurysm after the reconstruction of the segmental arteries at the thoracoabdominal aortic replacement. Patch aneurysm is often recognized after the thoracoabdominal aortic replacement, and the frequency is known to be high in patients with connective tissue disease such as LDS. The size of the patch at the initial operation could be presumed from the size of base of the aneurysm. The original patch was supposed to be too large. The huge patch was grown only 2 years after the initial surgery; therefore, we should apply this way of the reconstruction cautiously. The reconstruction is strongly related to the prevention of spinal cord dysfunction. Then, what was the adequate way of the reconstruction? Several novel techniques of the reconstruction of the small branch of aorta have been reported. ${ }^{4,5}$ Yet, they reported an aneurysmal change of the residual tissue at the segmental arteries during the follow-up period. ${ }^{6}$ At the moment we must focus to minimize the size of the native tissue at the patch, especially in patients with $\mathrm{LDS}^{7}$ The typical patient with LDS could be found easily and the caution could be paid to do the procedures; however, even patients with LDS might not always have typical features. I believe the age of the patient may be a significant issue to consider. When the patient for the procedure is young, short graft interposition or a minimum patch technique should be used for the reconstruction. ${ }^{8}$

The second issue is the use of the endovascular technique for patients with LDS. The use of endovascular therapy, even for great vessels in patients with LDS, is still

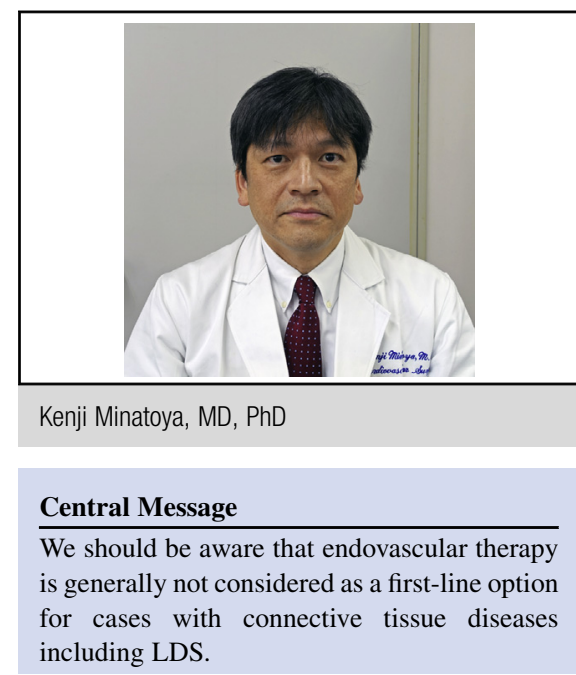

See Article page e95.

controversial. ${ }^{9}$ Redo procedures after left thoracotomy are indeed a challenge due to dense adhesion. Afifi and colleagues ${ }^{10}$ reported their experiences of such redo thoracoabdominal aortic aneurysm repair. They repaired the visceral and intercostal patch aneurysms with open surgical technique. The advance of the technology made the fine therapy of the technique as described by Tenorio and colleagues in this issue possible. However, if new lesion followed at the place of the small stent in future, open conversion would not be possible. Furthermore, the longterm results are entirely unknown. Several reports regarding endovascular therapy for peripheral vessels in patients with LDS have been published. These papers, however, only reported initial success and follow-up data up to around 5 years. ${ }^{11,12}$ Therefore, frequent and long-term postoperative surveillance imaging cannot be overemphasized in this challenging patient population. ${ }^{13}$

I heartily congratulate the authors' success with the exceptional technique in this case. Yet, we should be aware that endovascular therapy is generally not considered as a first-line option for cases with connective tissue diseases including LDS.

\section{References}

1. Loeys BL, Chen J, Neptune ER, Judge DP, Podowski M, Holm T, et al. A syndrome of altered cardiovascular, craniofacial, neurocognitive and skeletal development caused by mutations in TGFBR1 or TGFBR2. Nat Genet. 2005;37: $275-81$. 
2. Loeys BL, Schwarze U, Holm T, Callewaert BL, Thomas GH, Pannu H, et al. Aneurysm syndromes caused by mutations in the TGF-beta receptor. $N$ Engl $J$ Med. 2006;355:788-98.

3. Tenorio E, Tallarita T, Mirza A, Macedo TA, Oderich G. Endovascular repair of large intercostal artery patch aneurysm using branch stentgraft in a patient with Loeys-Dietz syndrome. J Thorac Cardiovasc Surg. 2020;159:e95-9.

4. Hu XP, Chang Q, Zhu JM, Yu CT, Liu ZG, Sun LZ. One-stage total or subtotal aortic replacement. Ann Thorac Surg. 2006;82:542-6.

5. Woo EY, Mcgarvey M, Jackson BM, Bavaria JE, Fairman RM, Pochettino A. Spinal cord ischemia may be reduced via a novel technique of intercostal artery revascularization during open thoracoabdominal aneurysm repair. $J$ Vasc Surg. 2007:46:421-6

6. Zhang L, Sun XG, Yu CT, Chang Q, Qian XY. Protection during thoracoabdominal aortic replacement. Intercostal artery reconstruction: the simple and effective technique on spinal cord. Ann Vasc Surg. 2016;34:62-7.

7. Dardik A, Perler BA, Roseborough GS, Williams GM. Aneurysmal expansion of the visceral patch after thoracoabdominal aortic replacement: an argument for limiting patch size? J Vasc Surg. 2001;34:405-9; discussion 410.

8. Henmi S, Ikeno Y, Yokawa K, Gotake Y, Nakai H, Yamanaka K, et al. Comparison of early patency rate and long-term outcomes of various techniques for reconstruction of segmental arteries during thoracoabdominal aortic aneurysm repair. Eur J Cardiothorac Surg. February 12, 2019 [Epub ahead of print].

9. Grabenwöger M, Alfonso F, Bachet J, Bonser R, Czerny M, Eggebrecht H, et al; European Association for Cardio-Thoracic Surgery (EACTS); European Society of Cardiology (ESC); European Association of Percutaneous Cardiovascular Interventions (EAPCI). Thoracic endovascular aortic repair (TEVAR) for the treatment of aortic diseases: a position statement from the European Association for Cardio-Thoracic Surgery (EACTS) and the European Society of Cardiology (ESC), in collaboration with the European Association of Percutaneous Cardiovascular Interventions (EAPCI). Eur J Cardiothorac Surg. 2012;42:17-24.

10. Afifi RO, Sandhu HK, Trott AE, Nguyen TC, Miller CC, Estrera AL, et al. Redo thoracoabdominal aortic aneurysm repair: a single-center experience over 25 years. Ann Thorac Surg. 2017;103:1421-8.

11. Beaulieu RJ, Lue J, Ehlert BA, Grimm JC, Hicks CW, Black JH III. Surgical management of peripheral vascular manifestations of Loeys-Dietz syndrome. Ann Vasc Surg. 2017;38:10-6.

12. Emmanuel Y, Gordon-Smith J, McKillop G, Duddy M, Clift P. Late peripheral thoracic aneurysms following aortic root surgery in patients with Loeys-Dietz syndrome. J Vasc Interv Radiol. 2015;26:1539-43.

13. Ohman JW, Charlton-Ouw KM, Azizzadeh A. Endovascular repair of an internal mammary artery aneurysm in a patient with Loeys-Dietz syndrome. J Vasc Surg. 2012;55:837-40. 